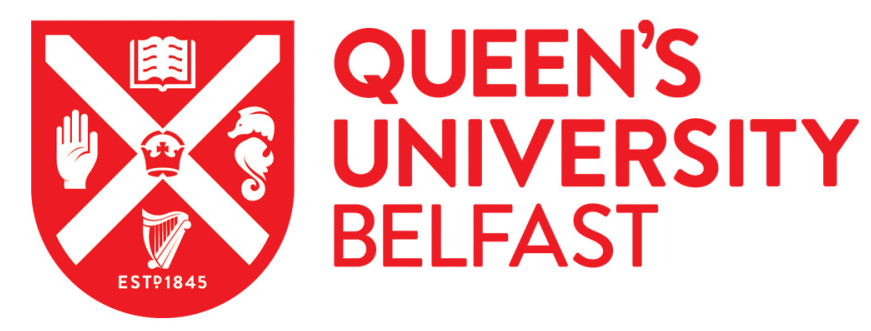

\title{
Intergroup resource distribution among children living in segregated neighborhoods amid protracted conflict
}

O'Driscoll, D., Taylor, L. K., \& Dautel, J. B. (2018). Intergroup resource distribution among children living in segregated neighborhoods amid protracted conflict. Peace and Conflict: Journal of Peace Psychology, 24(4), 464-474. https://doi.org/10.1037/pac0000348

Published in:

Peace and Conflict: Journal of Peace Psychology

Document Version:

Peer reviewed version

Queen's University Belfast - Research Portal:

Link to publication record in Queen's University Belfast Research Portal

Publisher rights

Copyright 2018 Taylor and Francis. This work is made available online in accordance with the publisher's policies. Please refer to any applicable terms of use of the publisher.

\section{General rights}

Copyright for the publications made accessible via the Queen's University Belfast Research Portal is retained by the author(s) and / or other copyright owners and it is a condition of accessing these publications that users recognise and abide by the legal requirements associated with these rights.

Take down policy

The Research Portal is Queen's institutional repository that provides access to Queen's research output. Every effort has been made to ensure that content in the Research Portal does not infringe any person's rights, or applicable UK laws. If you discover content in the Research Portal that you believe breaches copyright or violates any law, please contact openaccess@qub.ac.uk. 
INTERGROUP RESOURCE DISTRIBUTION AMONG CHILDREN

Running header: INTERGROUP RESOURCE DISTRIBUTION AMONG CHILDREN

Peace and Conflict: Journal of Peace Psychology, in press

\section{Intergroup resource distribution among children living in segregated neighborhoods amid protracted conflict}

Dean O’Driscoll, Laura K. Taylor, \& Jocelyn B. Dautel

Queen's University Belfast

The work was supported financially by the School of Psychology Research Incentivisation Scheme and Summer Student Scheme as well as through the countless hours of our undergraduate and masters research team. Dean O'Driscoll is supported by a Department of Employment and Learning (DEL) studentship [\#00417416]. The research was coordinated by Ellen White. Finally, we would like to extend our deep appreciation to the numerous school administrators, teachers, parents and pupils for participating in this study. Correspondence concerning this article should be addressed to Dean O'Driscoll, School of Psychology, 18 - 30 Malone Road, Belfast BT9 5BN, Northern Ireland. E-mail: dodriscol102@qub.ac.uk 


\begin{abstract}
Even after a peace agreement, children often grow up within societies characterized by division and simmering intergroup tensions. In Northern Ireland, segregated Protestant and Catholic neighborhoods occur side by side, separated by 'peace walls' or physical barriers that demarcate 'interface' areas, which have higher levels of violence compared to non-interface areas. The study explored the impact of living in interface and non-interface neighborhoods, the strength of ingroup identity, and outgroup attitudes on intergroup resource distributions of 88 children aged between 5 and 9 years old, growing up in Belfast. The findings revealed that compared to those in non-interface areas, children living in interface neighborhoods distributed more resources to an ingroup member than an outgroup member. This effect was accentuated for those children that more strongly identified with their community group, either Protestant or Catholic. At the same time, children with more positive outgroup attitudes distributed more resources to an outgroup member, but only in non-interface neighborhoods. By applying a framework that incorporates converging social and developmental processes, the study adds to a mounting body of research that aims to understand the impact of living in divided societies on children's intergroup attitudes and behaviors. The implications for promoting resource sharing across group lines within postaccord Northern Ireland are discussed.
\end{abstract}

Keywords: Northern Ireland, children's resource distribution, intergroup conflict, social identity, outgroup attitudes

\title{
Public Significance Statement
}

The study advances our understanding of children's distribution of resources across group lines within a divided society. The study highlights that within post-accord settings, 
peace-building initiatives need to consider the broader social context, more specifically how living in segregated neighborhoods influences social identity and intergroup attitudes. 


\section{Intergroup resource distribution among children living in segregated neighborhoods amid protracted conflict}

Young children may be particularly affected by settings afflicted by intergroup conflict (Cummings, Merrilees, Taylor, \& Mondi, 2017). Even following the declaration of ceasefires and the signing of peace-accords, the lives of children in post-accord regions often continue to be impacted by a legacy of conflict (Reidy et al., 2015). Post-accord societies are sometimes typified by segregation, as children reside within neighborhoods that are homogenous by ethnic group (Hughes, Campbell, Hewstone, \& Cairns, 2007) and attend separate schools (Ajduković \& Biruški 2008; Hayes \& McAllister, 2009). As children’s individual encounters with the former rival are often underpinned by segregation and simmering intergroup tensions (MacGinty, 2006), those born after the signing of peace accords may continue to propagate negative outgroup-directed attitudes and behaviors (Merrilees et al., 2017).

In contexts where long-standing intergroup dynamics remain a central part of an individual's day-to-day experience, there is a need to understand the underlying social psychological mechanisms (Bar-Tal, 2007). Operating within a developmental intergroup framework (Abrams \& Killen, 2014; Bennett \& Sani, 2004), the study explores the impact of living within segregated neighborhoods that vary in exposure to political violence. Within this context, the moderating role of strength of ingroup identity and outgroup attitudes on intergroup resource distribution among children in Northern Ireland's post-accord generation will be explored. Understanding factors that promote positive behaviors across group lines among children may inform peacebuilding initiatives within Northern Ireland, and other postaccord regions (McEvoy-Levy, 2006; Taylor et al., 2014; Taylor \& McKeown, 2017).

\section{Post-accord Northern Ireland}




\section{INTERGROUP RESOURCE DISTRIBUTION AMONG CHILDREN}

Northern Ireland has a long history of conflict between the Protestant and Catholic communities. However, despite the labelling of these community groups, the conflict was not fought only over religion, but instead can be conceptualized as a constitutional dispute between the competing political ideologies of Unionism/ Loyalism and Nationalism/Republicanism. That is, Unionists/Loyalists (mostly Protestant) identify as British and want Northern Ireland to remain a territory of the United Kingdom, whereas Nationalists/ Republicans (mostly Catholic) view themselves as Irish and aim to reunify the region with the Republic of Ireland (Darby, 1983; Moxon-Browne, 1991). Thus, the conflict is a political struggle with sectarian complications (Cairns, 1996), with religion being used as a marker of ethno-political identity (Cairns \& Darby, 1998).

The most recent upsurge of sectarian violence, known as 'The Troubles,' began in 1968 following civil rights demonstrations by Catholics for political and economic equality. However, this escalated into a violent conflict over ethno-political issues, such as nationality and the constitutional status of Northern Ireland (MacGinty, Muldoon, \& Ferguson, 2007). 'The Troubles' officially ended in 1998 with the signing of the Good Friday/ Belfast Agreement, which established a power-sharing government and designed policies to rectify intergroup inequalities. It has been estimated that 3,600 people were killed during the 30 -year period of conflict (McEvoy \& Shirlow, 2009), including 274 children (Fay, Morrissey, Smyth, \& Wong, 1999).

Despite seeing a reduction in direct military-style engagements and sectarian killings (Police Service of Northern Ireland, 2017), present-day Northern Ireland experiences a brittle peace. The society remains fractured along community lines (Gillespie, 2010), and polarized group identities underpin perceptions of "us" and "them" (McAuley \& Ferguson, 2016). A majority of children growing up as part of a post-accord generation have segregated lives. Approximately $93 \%$ of children attend segregated education (Northern Ireland Department of 
INTERGROUP RESOURCE DISTRIBUTION AMONG CHILDREN

Education, 2017), and may transition through both primary and post-primary school without ever meeting a member of the other community (O'Connor, Hartop, \& McCully, 2002).

Outside of school, children tend to live within close-knit neighborhoods that are majority Protestant or Catholic (Shuttleworth \& Lloyd, 2009; Lloyd \& Shuttleworth, 2012). Thus, children born after the signing of the peace-accord continue to be socialized in the legacy of the conflict (Reidy et al., 2015).

In areas where segregated Protestant and Catholic neighborhoods border each other, known as interface areas, relations between the two communities remain tense (Knox, 2011). Busy roads, security walls known as 'peace walls,' or other physical barriers often separate the abutting neighborhoods (Shirlow \& Murtagh, 2006). Historically, interface areas had been disproportionally affected by intergroup violence, with one in three conflict-related deaths between 1966 and 2001, taking place within less than 0.5 kilometers from a peace wall (Shirlow, 2003). Today, these areas continue to experience an annual cycle of violence (Ferman, 2013), with intermittent outbursts of political violence often taking the form of localized street fighting (Shirlow, 2001; McGrellis, 2005). These concentrated acts of intergroup hostility have the potential to extend beyond the confines of interface neighborhoods (Taylor et al., 2017), and place local children at risk of being directly exposed to political violence (Mesev, Shirlow, \& Downs, 2009). Particular concern has been raised for children living within these under-resourced and poverty affected areas, which are struggling to transition from intergroup conflict and upset (McAlister, Scraton, \& Haydon, 2014). These children tend to perceive political violence as a regular part of life (McAlister, Scraton, \& Haydon, 2009), and express feelings of insecurity and besiegement within interface neighborhoods (Leonard, 2006; McGrellis, 2010). As a consequence, children often develop a negative outlook on life (Hanson, 2005). By 7 to 8 years of age, many believe that 
they may be attacked or even killed if they venture across peace walls, and hold negative perceptions of the other community (Connolly \& Healy, 2004).

In comparison, non-interface areas comprise of neighborhoods not located near an interface or peace wall. That is, these areas do not abut territory occupied by the other community. Non-interface neighborhoods tend to vary by socioeconomic status; both economically disadvantaged and affluent neighborhoods could be classified as non-interface. Spatial division is linked to social class within non-interface areas, with residential segregation tending to be most prevalent in working class neighborhoods (Hughes, 2003). In recent years, outbreaks of intergroup conflict have decreased markedly within non-interface neighborhoods. However, little research has studied the influence living in these neighborhoods may have on the social development of children growing up as part of a postaccord generation. Previous work by Connolly and Healy (2004) found that within affluent non-interface neighborhoods, 7- to 11-year-old children were aware that they were members of either the Protestant or Catholic community, but for some, this identity was not salient. A majority of children tended to pathologize acts of political violence and did not display negative attitudes toward members of the other community (Connolly \& Healy, 2004).

\section{Development of Children's Intergroup Attitudes}

Research attempting to determine when and how children develop intergroup attitudes has primarily concentrated on early and middle childhood. Sociocognitive Theory (Aboud, 1988; Aboud \& Doyle, 1996) proposes that most 7-year-old children hold negative attitudes toward outgroup members. Whether these attitudes continue into later childhood is dependent on the development of enhanced perceptual and cognitive processes related to concrete operational thinking which assists children to recognize that variation exists between individuals (Doyle, Beaudet, \& Aboud, 1988). However, sociocognitive theory places little 
INTERGROUP RESOURCE DISTRIBUTION AMONG CHILDREN

importance on the role that the environment may have on the development of children's intergroup attitudes.

In comparison, by integrating cognitive, developmental, affective and group-based components, Social Identity Development Theory (SIDT) (Nesdale, 2004) proposes that children's intergroup attitudes are shaped by their knowledge of the surrounding social context (Bigler \& Liben, 2007). SIDT contends that not all children will develop outgroupdirected prejudice (Nesdale, 2007), which is the final step of a process that comprises of four consecutive phases: undifferentiated, ethnic awareness, ethnic preference and ethnic prejudice.

During the undifferentiated and ethnic awareness phases, 2- to 3-year-old children gain an awareness of social categories and self-identify as members of social groups. Selfidentification facilitates entry into the ethnic preference phase at around 4 years of age; characterized by children focusing on and displaying a preference for their ingroup. Group membership increases feelings of self-worth (Verkuyten, 2007), and thus children desire to be accepted rather than rejected by groups (Baumeister \& Leary, 1995). Children are guided by social motivations to achieve positive distinctiveness of their social group in comparison to other groups (Nesdale \& Flesser, 2001). Similarly, within their social group, children seek to consolidate their own position and boost their favorability with ingroup members (Cameron, Alvarez, Ruble, \& Fuligni, 2001). Children perceive themselves as similar to group members and display intergroup biases in their attitudes and behaviors, for example, increased liking of their own group over other groups (Bigler, Jones, \& Lobliner, 1997). Moreover, children with a stronger ingroup identity may be increasingly likely to exhibit intergroup biases (Nesdale, 2004). These intergroup biases, however, do not necessarily promote outgroup prejudice, as children may also hold positive attitudes toward other groups (Nesdale, 2007). 


\section{INTERGROUP RESOURCE DISTRIBUTION AMONG CHILDREN}

Children's transition from ethnic preference to ethnic prejudice is contingent upon the development of social-cognitive abilities, including perspective taking and empathy (Nesdale, Griffiths, Durkin, \& Maass, 2005), as well as intra- and intergroup processes within the social environment. For example, children may be encouraged to display explicit prejudice if their social group endorses norms of exclusion and outgroup dislike (Nesdale, 2004). Nesdale, Maass, Durkin and Griffiths (2005) suggest that ethnic prejudice would not be expected to occur in children under the age of 6 to 7 years old, as their social motivations and understanding of the surrounding environmental context would not be sufficiently developed to support dislike of other groups. However, this does not reflect the findings of research in conflict settings, where 2-to 3-year-old children have been shown to display negative attitudes toward the rival outgroup (e.g., for Northern Ireland see Connolly, Kelly, \& Smith, 2009; for Israel see Bar-Tal \& Teichman, 2005). Thus, the context of protracted intergroup violence may catalyze the transition from ethnic preference to ethnic prejudice much earlier than previously outlined (Bar-Tal, Diamond, \& Nasie, 2017; Nasie, Diamond, \& Bar-Tal, 2016). Nonetheless, a positive of SIDT is its emphasis on context, and this mirrors the wider field of peace psychology. For example, Christie (2006) notes that a key component of peace psychology is its sensitivity to the geohistorical context in which individuals are based. By suggesting that the context of intergroup conflict plays an important role in the development of children's prejudice, SIDT can be related to some of the components of systemic violence and peacebuilding. For example, continued exposure to a cycle of episodic violence may motivate children to heighten group identification and display intergroup biases in favor of their social ingroup (Nesdale, Durkin, Maass, \& Griffiths, 2005; Nesdale, Milliner, Duffy, \& Griffiths, 2009). These intergroup biases may then manifest as patterns of behaviors associated with structural violence, such as unfairly distributing resources to benefit the ingroup and deprive the outgroup. 
INTERGROUP RESOURCE DISTRIBUTION AMONG CHILDREN

\section{Children's Intergroup Resource Distribution}

From a young age, children show concern for the welfare of others (Eisenberg, Fabes, \& Spinrad, 1998), and place an importance on equality and fair treatment (Geraci \& Surian, 2011; Sloane, Baillargeon, \& Premack, 2012). However, despite this attentiveness to egalitarianism, developmental science has shown that children consider the status of relationships when allocating resources (Birch \& Billman, 1986; Fehr, Bernhard, \& Rockenbach, 2008). For example, children are likely to give more resources to their friends (Moore, 2009), and expect others to do the same (Paulus \& Moore, 2014).

The social environment of children, however, often extends beyond close interpersonal relationships. Given the importance that children place on group identity, it is surprising that relatively little research has explored children's group-based allocation of resources, particularly in settings where social groups are salient (Rutland \& Killen, 2017). By adulthood, group membership may influence decisions to allot resources between groups (Stepanikova, Triplett, \& Simpson, 2011). As a consequence, others may be denied access to resources on the basis of group membership, and this is regarded as a discriminatory act (Killen, Elenbaas, Rizzo, \& Rutland, 2017). Exploring the developmental origins of these intergroup biases may prove useful in formulating interventions to promote resource sharing across group lines, and these may have long-lasting implications.

When distributing resources between groups, children may be torn between desires for fairness and desires to assist their social ingroup (Rutland, Killen, \& Abrams, 2010). Sixyear-old children have been known to discard resources so that recipients can receive an equal share (Shaw \& Olson, 2012). However, when an egalitarian response is unavailable, children may be increasingly likely to display intergroup biases in their allocation of resources (Renno \& Shutts, 2015). For example, Spielman (2000) found that in a competitive minimal group setting, 5- to 6-year-old children exhibited a preference for members of their 
INTERGROUP RESOURCE DISTRIBUTION AMONG CHILDREN

own group when distributing resources. Children may be motivated to benefit their social ingroup in order to improve the overall position of the group and solidify links with group members (Goette, Huffman, \& Meier, 2006). Moreover, children aged 4 to 10 years also hold expectations that others will allocate more resources to their own group over other groups (DeJesus, Rhodes, \& Kinzler, 2014).

Research exploring children's resource distributions between socially salient groups has shown that children tend to allot more resources to unfamiliar individuals, with whom they share group membership, including race and gender (Dunham, Baron, \& Carey, 2011; Renno \& Shutts, 2015; Zinser, Rich, \& Bailey, 1981). However, noted exceptions exist. For example, 8- to 11-year-old children may distribute more resources to members of minority groups to rectify societal inequalities (Olson, Dweck, Spelke, \& Banaji, 2011).

In post-accord settings, where groups have longstanding histories of conflict, little is known about children's behaviors towards others. Ardila-Rey, Killen and Brenick (2009) found that experiencing political violence impacted 6- to 12-year-old Colombian children's reasoning regarding reconciliation and retaliation. Similarly, SIDT contends that continued exposure to a divided and conflict-ridden environment, may reduce children's willingness to assist outgroup members (Nesdale, 2004). Instead children may be driven to strengthen the status of their own group (Nesdale et al., 2009), including providing preferential treatment to those viewed as similar. Sustained exposure to political violence may heighten group cohesion (Taylor et al., 2011), and stronger ingroup identities may encourage members to organize and strive to secure societal change (Hammack, 2010). As a consequence of this intragroup cohesion in the face of an external threat, individuals may be increasingly motivated to benefit their social ingroup (Coser, 1956), which could diminish the prospect of children sharing resources across group lines. 
In contexts where intergroup dynamics are characterized by conflict, it is likely that members of a child's ingroup may disapprove of decisions to allocate resources to the perceived opponent. Previous research has shown that children that strongly identified with their social group tended to develop negative perceptions of disloyal ingroup members that conflicted with group-held norms (Abrams, Rutland, Ferrell, \& Pelletier, 2008). Expanding on this further, the 'black sheep effect' suggests that group members may be subjected to social penalties if they engage in behaviors that are not collectively endorsed (Abrams, Palmer, Rutland, Cameron, \& Van de Vyer, 2014; Pinto, Marques, Levine, \& Abrams, 2010). Engaging in positive acts toward the rival could jeopardize the position of members within their social group. Moreover, an individual's personal safety may be threatened as group members could decide to physically punish those seen to be collaborating with the opponent (Monaghan \& McLaughlin, 2006). The fear of intragroup backlash may assist in the maintenance of hostile intergroup relations and reduce the likelihood of children distributing resources to outgroup members.

\section{Current Study}

The current study recognizes the multiple ways that children living in post-accord settings, including Northern Ireland, actively engage with their environment (Taylor et al., 2014). At times, this engagement can be destructive, such as through participation in acts of political violence (Leonard, 2010). As a consequence, children are often blamed for perpetuating intergroup hostilities (Taylor \& McKeown, 2017). Yet, by viewing children primarily as troublemakers, it is easy to overlook the positive contributions they make in rebuilding society after periods of conflict (McEvoy-Levy, 2006). Therefore, an increasing body of research has aimed to uncover factors, which foster cooperation between previously conflicting groups (McEvoy-Levy, 2006); including the use of empathy (e.g., for Northern Ireland see Taylor \& Hanna, in press) intergroup contact (e.g., for Northern Ireland see Tam 
et al., 2008) and superordinate goals (e.g., for Israel see Kelman, 1990; for Sri Lanka see Malhotra \& Liyanage, 2005).

Adding to this literature, the current study explores the impact of living in interface and non-interface neighborhoods on the intergroup resource distribution of children growing up within post-accord Belfast. The role of ingroup identification and outgroup attitudes are also considered. By using SIDT as a theoretical lens, the study will investigate three research questions.

First, do children living in interface and non-interface neighborhoods display different patterns of behavior in their intergroup resource distributions? We propose that the continued cycle of violence within interface neighborhoods may heighten the salience of group identities and motivate children to exhibit stronger intergroup biases in favor of their community group compared to those in non-interface areas.

Second, in what way does strength of ingroup identity influence children's ingroup giving within these neighborhoods? Within interface neighborhoods, we expect children with both a high and low identification with their community group to give more resources to an ingroup member. Whereas, in non-interface neighborhoods, such ingroup biases are only expected for children that highly identify with their community group.

Finally, do outgroup attitudes have an effect on children's outgroup giving in these neighborhoods? It is hypothesized that outgroup attitudes will influence children's willingness to distribute resources to a member of the other community, but only in noninterface neighborhoods, given the potential repercussions of engaging in positive behaviors toward the perceived rival within settings of intergroup conflict.

\section{Method}

\section{Participants}


INTERGROUP RESOURCE DISTRIBUTION AMONG CHILDREN

One hundred and two children recruited from three primary schools within Belfast (two state controlled de facto Protestant schools and one Catholic-maintained school). Among those with parental consent to participate in the study, eight children were absent during the period of school-based data collection. Three sibling pairs participated in the study; to avoid nested data within families, the data of one sibling was randomly excluded from further analyses. Another three children were omitted from the analyses, as parents had reported that the family was not native to Northern Ireland and had immigrated to the region within the past three years. The final sample comprised of 88 children aged between 5 and 9 years old $(M=7.5$ years, $S D=1.4)$. The sample was roughly split by community background and gender: $48.9 \%$ of participants were Protestant $(n=43 ; 23$ male, 20 female $)$ and $51.1 \%$ were Catholic ( $n=45 ; 23$ male, 22 female). All participants were born after the signing of the Good Friday/ Belfast Agreement, and were growing up as part of a post-accord generation.

Participating primary schools were selected based on their geographical location within Belfast, specifically whether they were located within interface (one state controlled, one Catholic-maintained) or non-interface areas (one state controlled). To control for the high level of residential segregation and economic deprivation that affect interface neighborhoods (Shirlow, 2003), schools located within non-interface neighborhoods were matched for homogeneity of pupils and socioeconomic status. All schools were highly segregated, with more than $70 \%$ of the total enrolled pupils comprising solely from one of the two dominant communities within Northern Ireland, either Protestant or Catholic. The proportion of pupils receiving free school meals was used as a proxy variable of socioeconomic status (Hughes, Blaylock, \& Donnelly, 2015). Over $70 \%$ of pupils in each primary school received free school meals, and schools were located within working-class areas.

\section{Procedure}


Before the study began, principals gave consent to facilitate data collection within their school. A packet was sent home to all children in the eligible year groups that contained an information sheet and a parental consent form to be returned to the child's school once completed. Children with parental consent also provided written consent prior to initiating the study. Children then individually completed a series of tasks, lasting approximately 15 minutes, with a trained experimenter in a quiet area of their school. Children were trained on how to use the simplified Likert-type scales before proceeding to the primary questions and tasks. At the completion of the study, each child received a small prize and a certificate of participation. Moreover, each primary school received a $£ 75$ Amazon gift voucher, and participating parents were entered into a lottery to win one of ten $£ 25$ Amazon gift vouchers.

\section{Measures}

Strength of ingroup identity. Strength of ingroup identity was assessed using a 3item scale adapted from a quasi-experimental intergroup design with children aged 5 to 11 years (Cameron, Rutland, Brown, \& Douch, 2006). As part of the current study, participants were presented with a photograph pair of ingroup children (1 male, 1 female) and reported on a 5-point bipolar scale ranging from 0 "not at all" to 4 "very much so" on the extent to which they liked, took pride in and the importance of being a member of their community group, either Protestant or Catholic. Higher scores indicated a greater strength of ingroup identity (Cronbach's $\alpha=.90)$.

Outgroup attitudes. Outgroup attitudes were assessed toward members of the other community using a measure developed by Nesdale et al. (2010) for minimal group research with children between the ages of 7 to 9 years. In the current study, participants reported on three single-item scales the extent to which they liked, trusted and would like to play with members of the other community. Participants reported on each item on a 5-point bipolar scale from 0 to 4, for example, 0 ("I don't like them at all") to 4 ("I like them a lot"). Scores 
ranged from 0 to 12 , with higher scores indicating more positive attitudes toward outgroup members (Cronbach's $\alpha=.84)$.

Resource task. To assess intergroup resource distribution, participants were shown a photograph of two gender-matched, smiling, primary school aged children. Children presented in the photograph pairs were deemed to be of similar levels of attractiveness by an adult rater and the photographed children were not known to the participant.

To manipulate group membership, participants were explicitly told that the children in the photographs were Protestant or Catholic. These children were also depicted wearing different color t-shirts (orange for Protestant and green for Catholic), and were given prototypical forenames (e.g. Elizabeth for Protestant child vs. Siobhán for Catholic child). Photographs were counterbalanced across participants.

Participants were made aware that each of the children in the photographs was sick in the hospital. Participants were given seven, sparkly smiley face stickers to distribute between the ingroup and outgroup child, and informed that the experimenter would deliver the stickers during an upcoming visit to the hospital. A small, color-matched (orange for Protestant and green for Catholic) cardboard collection box was placed beside each photograph.

Adopting a similar approach to other work on children's group-based distribution of resources (Rhodes, Leslie, Saunders, Dunham, \& Cimpian, 2017), decisions to allocate stickers between an ingroup and outgroup member were non-costly, as participants were unable to keep stickers for themselves. Participants were instructed to place the stickers for each child in separate cardboard boxes and to close each box once they had finished. To limit the influence of the experimenter on the child's decision, he or she turned away from the child and shuffled papers and did not turn around until both collection boxes had been closed. 
INTERGROUP RESOURCE DISTRIBUTION AMONG CHILDREN

The total number of stickers placed in the collection box for the ingroup child provided a score of ingroup giving, while the total amount of stickers placed in the collection box for the outgroup child provided a score of outgroup giving. Scores ranged from 0 to 7.

\section{Results}

Table 1 displays the means, standard deviations and bivariate correlations for all research variables. An independent samples t-test revealed a significant effect of neighborhood type on children's ingroup giving scores $(t(86)=3.64, p<.001)$, with children living in interface neighborhoods giving more stickers to an ingroup member $(\mathrm{M}=3.93, \mathrm{SD}$ $=1.12)$, than children in non-interface neighborhoods $(\mathrm{M}=2.86, \mathrm{SD}=1.61)$. No significant effect of neighborhood type was noted on children's outgroup giving scores $(t(86)=.356, p$ $=.72$ ), with children in interface neighborhoods giving a comparable number of stickers to an outgroup member $(\mathrm{M}=3.07, \mathrm{SD}=1.12)$ as those in non-interface neighborhoods $(\mathrm{M}=2.95$, $\mathrm{SD}=1.80)($ Figure 1).

While the photographs were always gender-matched to the participant, general differences in the resource distributions of male and female participants were explored. An independent samples t-test found no significant effect of gender on children's ingroup giving scores $(t(86)=1.43, p=.63)$. That is, both males $(\mathrm{M}=3.20, \mathrm{SD}=1.54)$ and females $(\mathrm{M}=$ $3.64, \mathrm{SD}=1.38)$ tended to give a similar number of stickers to a gender-matched ingroup member. Likewise, no significant effect of gender was found on children's outgroup giving scores $(t(86)=6.43, p=.76)$, with males $(\mathrm{M}=3.11, \mathrm{SD}=1.58)$ and females $(\mathrm{M}=2.90, \mathrm{SD}$ $=1.38$ ) giving roughly the same number of stickers to a gender-matched outgroup member.

Moderation analysis was then tested using Model 1 in PROCESS (Hayes, 2013) in SPSS 21, with age being included as a demographic control. Despite no gender differences in children's ingroup and outgroup resource distribution, gender was also controlled for within this analysis. The moderation was bootstrapped with 5,000 replications and statistical 
significance was assessed using 95\% bias-corrected confidence intervals. Independent and moderating variables were mean centered before the analysis was conducted (Aiken \& West, 1991), and unstandardized regression coefficients were reported (Hayes, 2013).

Ingroup giving. Moderation analysis was conducted to assess whether strength of ingroup identity moderated the relationship between neighborhood type and children's ingroup giving. The demographic control variables of child age $(b=.06, \mathrm{se}=.11, p=.602)$ and gender $(\mathrm{b}=.41, \mathrm{se}=.29, p=.167)$ did not significantly predict ingroup giving. A significant main effect of neighborhood type was noted $(b=1.09$, se $=.30, p<.001)$, with living in interface neighborhoods predicting greater ingroup giving. A significant ingroup identity $\mathrm{x}$ neighborhood type interaction effect $(\mathrm{b}=-.24$, $\mathrm{se}=.12, p=.049)$ revealed that for children with a higher strength of ingroup identity, there were no differences in ingroup giving scores between interface and non-interface neighborhoods. However, neighborhood differences were present for children with a lower strength of ingroup identity; children in interface neighborhoods gave more stickers to an ingroup member compared to those living in non-interface areas. That is, within interface neighborhoods, regardless of strength of ingroup identity, children likely to give more stickers to an ingroup member. In comparison, within non-interface neighborhoods, only children with a stronger ingroup identity were more likely to give to an ingroup member (Figure 2).

Outgroup giving. A separate moderation analysis examined whether the association between neighborhood type and outgroup giving was moderated by outgroup attitudes. As with ingroup giving, demographic controls of children's age $(b=-.10, \mathrm{se}=.11, p=.352)$ and gender $(\mathrm{b}=-.21, \mathrm{se}=.30, p=.494)$ did not significantly predict outgroup giving. A significant main effect was noted for outgroup attitudes being related to increased outgroup giving $(\mathrm{b}=.14$, se $=.06, p=.019)$. However, a significant outgroup attitudes $\mathrm{x}$ neighborhood type interaction revealed that this effect only held for children living in non-interface 
neighborhoods $(\mathrm{b}=-.24$, se $=.11, p=.039)$. That is, for children living within non-interface neighborhoods, those with higher outgroup attitudes gave more stickers to an outgroup child than those with lower outgroup attitudes; this relation was not present for children living in interface neighborhoods (Figure 3).

\section{Discussion}

Although research has studied children's resource allocation in both minimal and socially relevant contexts (Killen et al., 2017), less is known about how resources are distributed between groups with longstanding histories of conflict. Moreover, few empirical papers have used Social Identity Development Theory (SIDT) to examine the importance of context on the social development of children. The current study aimed to explore the impact of living in interface and non-interface neighborhoods, strength of ingroup identity, and outgroup attitudes on intergroup resource distribution among children growing up within post-accord Belfast. The study was also the first to select schools located in interface and non-interface neighborhoods that had similar levels of socioeconomic status and level of segregation. This was a strength of the study, as it allowed for comparisons to be made across matched populations. The findings suggest that resource distribution across group lines is affected by the context in which children are raised. Thus, providing support to both SIDT as a theory and the emphasis on context within peace psychology.

Children with a high strength of ingroup identity and those living in interface neighborhoods were more likely to provide resources to a member of their community group. The finding is consistent with SIDT. That is, children that strongly identify with their social ingroup are likely to exhibit intergroup biases in favor of their group (Nesdale, Durkin et al., 2005). Giving more resources to one's ingroup helps to achieve positive distinctiveness of their social group in comparison to other groups (Nesdale \& Flesser, 2001). Similarly, sustained exposure to political violence in interface neighborhoods may heighten identity 
salience and encourage children to engage in behaviors that maintain, defend or enhance the status of their group (Nesdale et al., 2009). For example, even for children with lower ingroup identity, living in an interface neighborhood was related to giving more resources to an ingroup member. The continuation of a cycle of episodic violence within interface areas, may heighten ingroup cohesion (Taylor et al., 2011) and leave children increasingly motivated to advantage members of their social group, rather than share resources across group lines (Coser, 1956). These inequalities in children's resource distributions reflect behaviors associated with structural violence, as they benefit the ingroup while depriving the outgroup (Christie, 2006). Despite the signing of the peace-accord, hostile intergroup dynamics are preserved within interface neighborhoods and life remains binary. An increased emphasis is therefore placed on ingroup identity and this influences interaction in personal, professional and educational life (Shirlow \& Murtagh, 2006).

The results also indicate that outgroup attitudes influence children's intergroup resource distributions, but only for those living in non-interface settings. That is, within interface neighborhoods, children's outgroup attitudes did not influence decisions to allocate resources to a member of the other community. Across development, children gain a greater knowledge of intragroup dynamics and recognize that the motivations and expectations of a group differ from those of individuals (Nesdale, Killen, \& Duffy, 2013). Children learn that members are expected to be prototypical of a group, and display mutually held attitudes and behaviors that are considered to be acceptable (Abrams et al., 2008). The continued escalation and de-escalation of violence in interface neighborhoods (Ferman, 2013), contributes to the generation of a zero-sum outlook, where a benefit to one community is detriment to the other.

In such a context, group members may view sharing resources with the other community as benefitting the opponent at the expense of the communal ingroup, and 
individuals engaging in these acts may be subjected to social or physical punishments (Monaghan \& McLaughlin, 2006). On the one hand, the decisions of children within interface neighborhoods to allocate resources to a member of the other community may have been driven by their knowledge of intragroup dynamics and an aversion to intragroup threat, rather than outgroup attitudes. On the other hand, children living in non-interfaced neighborhoods may have more variance in their knowledge of the other community. That is, given the reduced exposure to intergroup conflict within these neighborhoods, children that no longer view the other community as the traditional rival may display more positive attitudes, than those that continue to perceive intergroup relations as hostile. The findings in non-interface neighborhoods may be indicative of what Bar-Tal and Halperin (2009) describe as the 'unfreezing process' of traditional conflict dynamics (Taylor et al., 2014). That is, when individuals are presented with information that is incompatible with previous perceptions of intergroup relations and this drives a search for alternative information (BarTal \& Halperin, 2009). The lower exposure to political tension within non-interface settings may reduce ingroup interdependence (Flippen, Hornstein, Siegal, \& Weizman, 1996), and motivate children to recalibrate longstanding perceptions of the other community and display positive behaviors toward the former rival.

The findings contribute to our knowledge of how children distribute resources between socially salient groups. They also highlight the need to consider the broader social context when exploring the intergroup attitudes and behaviors of children growing up within post-accord regions. However, critical open questions remain.

First, by matching interface and non-interface neighborhoods for level of segregation and socioeconomic status, an additional neighborhood type was excluded from the study's design; affluent non-interface neighborhoods. These affluent neighborhoods tend to experience a greater heterogeneity of residents (Shirlow, 2001), and children living in these 
neighborhoods are increasingly likely to attend integrated schools (Hewstone, Cairns, Voci, Hamberger, \& Niens, 2006). In order to gain a more comprehensive understanding of the social development of children within post-accord Northern Ireland, future research should consider recruiting samples from interface neighborhoods as well as economically disadvantaged and affluent non-interface neighborhoods.

Second, an increasing body of research has indicated that the resource distributions of children may be influenced by expectations of social reciprocity (DeJesus et al., 2014). In that, children may allocate more resources to people they believe will assist them in return (Renno \& Shutts, 2015; Rhodes et al., 2015). Children's perceived reciprocity of ingroup and outgroup members was not assessed in the current study. Future research should explore whether expectations of social reciprocity may account for the divergent findings in children's intergroup resource distribution noted between interface and non-interface neighborhoods.

Finally, given the cross-sectional nature of the study, it is difficult to make causal inferences. For example, within non-interface neighborhoods, positive outgroup attitudes may influence children's distribution of resources across group lines. However, an increased willingness to share resources with a member of the other community could also lead to more positive attitudes. Future research should confirm the direction of these relationships using longitudinal data. The current study provides the ground-work for future research to unravel these causal patterns; for example, by exploring whether children's behavior would change if they moved out of an interface neighborhood. However, this question may be more theoretical than practical, as high levels of economic deprivation mean that it is almost impossible for people to move out of these neighborhoods (Shirlow, 1999). Families therefore often develop a perception of possessing links to the local area, with generations of family members living within close proximity. From an early age, children living within 
these areas develop an emotional attachment to their immediate locality (Connolly \& Healy, 2004). The local area demarcates the boundaries of children's social environment, and provides a standard to which information is compared when learning and gaining an understanding of the world (Connolly \& Neill, 2001).

The results of the current study have implications for practitioners aiming to promote resource sharing across group lines within post-accord Northern Ireland. Previous research has demonstrated the benefits of stronger ingroup identity in this context (Merrilees et al., 2014). That is, ingroup identity can buffer some of the negative effects of exposure to political violence, by providing a prism through which children can interpret the conflictrelated events unfolding within their local environment (Punamäki, 1996; Merrilees et al., 2014). However, the current study suggests that interventions aiming to influence strength of ingroup affiliation and connection may only be effective for children with low ingroup identification in non-interface settings. Future research is needed to better understand how to encourage resource sharing across group lines for those with stronger ingroup identities and among children living in interface neighborhoods. It may be more beneficial for peacebuilding programs to work with these identities but against violence. For example, educational interventions that aim to build upon respect for others, forgiveness and inclusion, may prove effective in motivating children to engage in positive outgroup-directed behaviors (Tropp, O’Brien, \& Migacheva, 2014). The use of such interventions would be supported by SIDT, which would predict that prejudice may be reduced in children with a heightened strength of ingroup identity by developing norms of inclusion rather than exclusion (Nesdale, Maass et al., 2005).

Given that the patterns of behavior noted by children living in non-interface neighborhoods may be due increased variance in their knowledge of the other community; for example, through a greater exposure to diversity in these areas, and more contact 
opportunities without the presence of divisive peace walls. This could provide supporting evidence for the use of programs such as integrated education. Integrated schools provide an inclusive teaching environment where Protestant and Catholic pupils learn within the same classroom. In addition, through the provision of peace-education, these pupils are also taught to respect intergroup differences and appreciate diversity (Gallagher, 2010). Similarly, projects that partner segregated Protestant and Catholic schools for joint activities may also prove useful in promoting positive out-group directed behaviors. For example, experiencing positive intergroup exchanges may reduce anger over previous transgressions, while encouraging empathy and forgiveness (Tam et al., 2008).

However, previous school-based contact interventions within interface neighborhoods have met significant challenges. In particular, children expressed feelings of fear and intimidation, were hesitant to discuss topics related to the conflict, and were unwilling to voluntarily interact with members of the other community (Hughes, 2013). Others tended to perceive the contact as negative, and believed that ingroup members would disapprove of their involvement in cross-community programs (Hughes et al., 2015). In order to address these barriers, it may be useful for future school-based interventions to introduce the use cooperative games that have a superordinate goal (Sherif, Harvey, White, Hood, \& Sherif, 1961). These games would encourage Protestant and Catholic children join forces to achieve a shared objective, without requiring them to give up their ingroup identity (Batson \& Ahmad, 2009). Given that the two groups are dependent on each other, conflict is not productive. Thus, children are pushed to consider the perspectives of outgroup members, while also being sensitive to their requests and needs (Batson \& Ahmad, 2009). This may be an enjoyable and collaborative experience for children, and may form the basis for sharing resources across group lines. However, the findings of the current study and previous contact programs (Hughes et al., 2015) have shown that within interface neighborhoods, children 
may be less willing to cooperate with outgroup members due to an aversion to intragroup threat. As such, there is a need for future interventions to also include the wider community. For example, local leaders could take part in and endorse these interventions, or former paramilitary members who have opted for peace could share their stories. That is, by involving community members from outside of the school environment, this may generate a perception of ingroup approval.

The study adds to our understanding of children's allocation of resources across group lines within a post-accord setting. Despite almost 20 years since the signing of the peaceaccord, Northern Ireland has retained a zero-sum culture, which threatens the stability of the peace process. For example, the region's power-sharing government continues to provide legitimacy to longstanding community divisions (MacGinty et al., 2007), as elected representatives are labelled as 'Protestant-Unionist', 'Catholic-Nationalist' or 'Other.' As a consequence, political stalemates are common with frequent collapse when the two sides cannot agree how to distribute funding, the most recent of which occurred in January 2017. Thus, understanding resource distribution, even among children, in post-accord Northern Ireland may help to inform future peace-building initiatives. Furthermore, if peace building involves adjusting perceptions of intergroup dynamics (Lederach, 1997), so that the former rival can be viewed as an equal partner in building a shared future, then there is a need to focus on the post-accord generation (McEvoy-Levy, 2006). In particular, programs that encourage youth to engage in positive behaviors across group lines may help dismantle the entrenched and polarized nature of Northern Irish society. These may also have important implications for other post-accord settings, or regions engaged in active intergroup conflict. 
INTERGROUP RESOURCE DISTRIBUTION AMONG CHILDREN

\section{References}

Aboud, F. (1988). Children and prejudice. Oxford: Blackwell.

Aboud, F.E., \& Doyle, A. (1996). Parental and peer influences on children's racial attitudes. International Journal of Intercultural Relations, 20, 371-383.

Abrams, D., \& Killen, M. (2014). Social exclusion of children: Developmental origins of prejudice. Journal of Social Issues, 70(1), 1-11.

Abrams, D., Palmer, S.B., Rutland, A., Cameron, L., \& Van de Vyver, J. (2014). Evaluations of and reasoning about normative and deviant ingroup and outgroup members: Development of the black sheep effect. Developmental Psychology, 50(1), 258-270.

Abrams, D., Rutland, A., Ferrell, J.M., \& Pelletier, J. (2008). Children's judgments of disloyal and immoral peer behaviour: Subjective group dynamics in minimal intergroup contexts. Child Development, 79(2), 444-461.

Aiken, L.S., \& West, S.G. (1991). Multiple Regression: Testing and interpreting interactions. Newbury Park, CA: Sage.

Ajduković, D., \& Biruški, D.C. (2008). Caught between the ethnic sides: Children growing up in a divided post-war community. International Journal of Behavioural Development, 32(4), 337-347.

Ardila-Rey, A., Killen, M., \& Brenick, A. (2009). Moral Reasoning in Violent Contexts: Displaced and Non-displaced Colombian Children's Evaluations of Moral Transgressions, Retaliation, and Reconciliation. Social Development, 18(1), 181-209.

Bar-Tal, D. (2007). Sociopsychological foundations of intractable conflict. American Behavioural Scientist, 50(11), 1430-1453.

Bar-Tal, D., Diamond, A.H., \& Nasie, M. (2017). Political socialization of young children in intractable conflicts: Conception and Evidence. International Journal of Behavioral Development, 41(3), 415-425. 
INTERGROUP RESOURCE DISTRIBUTION AMONG CHILDREN

Bar-Tal, D., \& Halperin, E. (2009). Overcoming psychological barriers to peace making: The influence of mediation beliefs about losses. In M. Mikulincer, \& P.R. Shaver (Eds.), Prosocial motives, emotions and behavior (pp. 431-448). Washington, DC: American Psychological Association Press.

Bar-Tal, D., \& Teichman, Y. (2005). Stereotypes and prejudice in conflict: Representations of Arabs in Israel Jewish Society. Cambridge: Cambridge University Press.

Batson, C.D., \& Ahmad, N.Y. (2009). Using empathy to improve intergroup attitudes and relations. Social Issues and Policy Review, 3(1), 141-177.

Baumeister, R.F., \& Leary, M.R. (1995). The need to belong: desire for interpersonal attachments as a fundamental human motivation. Psychological Bulletin, 117(3), 497.

Bennett, M., \& Sani, F. (Eds.). (2004). The development of the social self. Sussex, UK: Psychology Press.

Bigler, R.S., Jones, L.C., \& Lobliner, D.B. (1997). Social categorisation and the formation of intergroup attitudes in children. Child Development, 68(3), 530-543.

Bigler, R.S., \& Liben, L.S. (2007). Developmental intergroup theory: Explaining and reducing children's social stereotyping and prejudice. Current Directions in Psychological Science, 16(3), 162-166.

Birch, L.L., \& Billman, J. (1986). Preschool children's food sharing with friends and acquaintances. Child Development, 57, 387-395.

Cairns, E. (1996). Children and political violence. Oxford: Blackwell.

Cairns, E., \& Darby, J. (1998). The conflict in Northern Ireland: Causes, consequences and controls. American Psychologist, 53(7), 754-760. 
Cameron, J.A., Alvarez, J.M., Ruble, D.N., \& Fuligni, A.J. (2001). Children's lay theories about ingroups and outgroups: Reconceptualizing research on prejudice. Personality and Social Psychology Review, 5(2), 118-128.

Cameron, L., Rutland, A., Brown, R., \& Douch, R. (2006). Changing Children's Intergroup Attitudes Toward Refugees: Testing different models for extended contact. Child Development, 77(5), 1208-1219.

Christie, D.J. (2006). What is peace psychology the psychology of? Journal of Social Issues, 62(1), 1-17.

Connolly, P., \& Healy, J. (2004). Children and the conflict in Northern Ireland: The experiences and perspectives of 3-11 year olds. Belfast: Office of the First Minister and Deputy First Minister.

Connolly, P., \& Neill, J. (2001). Constructions of locality and gender and their impact on the educational aspirations of working-class children. International Studies in Sociology of Education, 11(2), 107-129.

Connolly, P., Smith, A., \& Kelly, B. (2009). Ethnic habitus and young children: a case study of Northern Ireland. European Early Childhood Research Journal, 17(2), 217-232.

Coser, L.A. (1956). The functions of social conflict. New York: Free Press.

Cummings, E.M., Merrilees, C.E., Taylor, L.K., \& Mondi, C.F. (2017). Developmental and social-ecological perspectives on children, political violence, and armed conflict. Development and Psychopathology, 29(1), 1-10.

Darby, J. (1983). Northern Ireland: The Background to the Conflict. New York: Appletree.

DeJesus, J.M., Rhodes, M., \& Kinzler, K.D. (2014). Evaluations versus expectations: Children's divergent beliefs about resource distribution. Cognitive Science, 38(1), 178-193. 
Doyle, A.B., Beaudet, J., \& Aboud, F. (1988). Developmental patterns in the flexibility of children's ethnic attitudes. Journal of Cross-Cultural Psychology, 19(1), 3-18.

Dunham, Y., Baron, A.S., \& Carey, S. (2011). Consequences of 'minimal' group affiliations in children. Child Development, 82(3), 793-811.

Eisenberg, N., Fabes, R.A., \& Spinrad, T.L. (1998). Prosocial development. In N.Eisenberg \& W. Damon (Eds.), Handbook of child psychology (pp. 646-718). New York: Wiley.

Fay, M.T., Morrissey, M., Smyth, M., \& Wong, T. (1999). The Cost of the Troubles Study: Report on the Northern Ireland Survey: the experience and impact of the Troubles. Belfast: INCORE.

Fehr, E., Bernhard, H., \& Rockenbach, B. (2008). Egalitarianism in young children. Nature, $454,1079-1081$.

Ferman, D. (2013). A parade or a riot: A discourse analysis of two ethnic newspapers on the 2011 marching season in Northern Ireland. Journal of Media and Religion, 12(2), 55 70.

Flippen, A.R., Hornstein, H.A., Siegal, W.E., \& Weitzman, E.A. (1996). A comparison of similarity and interdependence as triggers for in-group formation. Personality and Social Psychology Bulletin, 22(9), 882-893.

Gallagher, T. (2010). Building a shared future from a divided past. Promoting peace through education in Northern Ireland. In G. Salomon \& E. Cairns (Eds.), Handbook on peace education (pp. 241-251). New York: Psychology Press.

Geraci, A., \& Surian, L. (2011). The developmental roots of fairness: Infant's reactions to equal and unequal distributions of resources. Developmental Science, 14(5), 10121020.

Gillespie, G. (2010). A short history of the Troubles. Dublin: Gill and Macmillan. 
INTERGROUP RESOURCE DISTRIBUTION AMONG CHILDREN

Goette, L., Huffman, D., \& Meier, S. (2006). The impact of group membership on cooperation and norm enforcement: Evidence using random assignment to real social groups. The American Economic Review, 96(2), 212-216.

Hammack, P.L. (2010). Identity as burden or benefit? Youth, historical narrative, and the legacy of political conflict. Human Development, 53(4), 173-201.

Hanson, U. (2005). Troubled youth? Young people, violence and disorder in Northern Ireland. Belfast: Institute for Conflict Research.

Hayes, A.F. (2013). Introduction to mediation, moderation, and conditional process analysis: A regression-based approach. New York: The Guilford Press.

Hayes, B.C., \& McAllister, I. (2009). Education as a mechanism for conflict resolution in Northern Ireland. Oxford Review of Education, 35(4), 437-450.

Hewstone, M., Cairns, E., Voci, A., Hamberger, J., \& Niens, U. (2006). Intergroup contact, forgiveness, and experience of "The Troubles" in Northern Ireland. Journal of Social Issues, 62(1), 99-120.

Hughes, J. (2013). Contact and context: sharing education and building relationships in a divided society. Research papers in Education, 29(2), 1-18.

Hughes, J., Blaylock, D., \& Donnelly, C. (2015) Does social deprivation influence intergroup contact outcomes for pupils in Northern Ireland? Ricerche di Pedagogia e Didattica. Journal of Theories and Research in Education, 10(1), 47-65.

Hughes, J., Campbell, A., Hewstone, M., \& Cairns, E. (2007). Segregation in Northern Ireland: implications for community relations policy. Policy Studies, 28(1), 33-53.

Kelman, H.C. (1990). Interactive problem-solving: A social psychological approach to conflict resolution. In J.W. Burton \& F. Dukes (Eds.), Conflict: Readings in management and resolution (pp. 199-215). New York: St Martin's Press. 
Killen, M., Elenbaas, L., Rizzo, M.T., \& Rutland, A. (2017). The role of group processes in social exclusion and resource allocation decisions. In A. Rutland, D. Nesdale, C. Spears-Brown (Eds.), The Wiley Handbook of Group Processes in Children and Adolescents (pp. 99-123). New York: Wiley

Knox, C. (2011). Peace Building in Northern Ireland: A Role for Civil Society. Social Policy \& Society, 10(1), 1-16.

Lederach, J.P. (1997). Building peace: Sustainable reconciliation in divided societies. Washington, D.C: United States Institute of Peace Press.

Leonard, M. (2006). Teens and territory in contested spaces: Negotiating sectarian interfaces in Northern Ireland. Children's Geographies, 4(2), 225-238.

Leonard, M. (2010). Parochial geographies: Growing up in divided Belfast. Childhood: A Global Journal of Child Research, 17(3), 329-342.

Lloyd, C.D., \& Shuttleworth, I.G. (2012). Residential segregation in Northern Ireland in 2001: Assessing the value of exploring spatial variations. Environment and Planning A, 44(1), 52-67.

MacGinty, R. (2006). No war, no peace: The rejuvenation of stalled peace processes and peace accords. Basingstoke, UK: Palgrave Macmillan.

MacGinty, R., Muldoon, O., \& Ferguson, R. (2007). No War, No Peace: Northern Ireland after the Agreement. Political Psychology, 28(1), 1-11.

Malhotra, D., \& Liyanage, S. (2005). Long-term effects of peace workshops in protracted conflicts. Journal of Conflict Resolution, 49(6), 908-924.

McAlister, S., Scraton, P., \& Haydon, D. (2009). Childhood in transition: Experiencing marginalization and conflict in Northern Ireland. Children's Geographies, 12(3), 297311. 
INTERGROUP RESOURCE DISTRIBUTION AMONG CHILDREN

McAlister, S., Scraton, P., \& Haydon, D. (2014). Childhood in transition: growing up in 'post-conflict' Northern Ireland. Children’s Geographies, 12(3), 297-311.

McAuley, J.W., \& Ferguson, N. (2016). “Us" and "Them”: Ulster Loyalist Perspectives on the IRA and Irish Republicanism. Terrorism and Political Violence, 28(3), 561-575.

McEvoy-Levy, S. (2006). Troublemakers or Peacemakers? Youth and Post-Accord Peacebuilding. Notre Dame, IN: Notre Dame Press.

McEvoy, K., \& Shirlow, P. (2009). Re-imagining DDR ex-combatants, leadership and moral agency in conflict transformation. Theoretical Criminology, 13(1), 31-59.

McGrellis, S. (2005). Pushing the boundaries in Northern Ireland: young people, violence and sectarianism. Contemporary Politics, 11(1), 53-71.

McGrellis, S. (2010). In Transition: Young People in Northern Ireland Growing Up in, and out of, Divided Communities. Ethnic and Racial Studies, 33(5), 761-778.

Merrilees, C.E., Taylor, L.K., Goeke-Morey, M.C., Shirlow, P., Cummings, E.M., \& Cairns, E. (2014). The protective role of group identity: Sectarian antisocial behaviour and adolescent emotion problems. Child Development, 85(2), 412-420.

Merriless, C.E., Taylor, L.K., Baird, R., Goeke-Morey, M.C., Shirlow, P., \& Cummings, E.M. (2017). Neighborhood Effects of Intergroup Contact on Change in Intergroup Bias. Journal of Youth and Adolescence, 47(1), 77-87.

Mesev, V., Shirlow, P., \& Downs, J. (2009). The geography of conflict and death in Belfast, Northern Ireland. Annals of the Association of American Geographers, 99(5), 893903.

Monaghan, R., \& McLaughlin, S. (2006). Informal justice in the city. Space and Polity, 10(2), 171-186.

Moore, C. (2009). Fairness in children's resource allocation depends on the recipient. Psychological Science, 20(8), 944-948. 
INTERGROUP RESOURCE DISTRIBUTION AMONG CHILDREN

Moxon-Brown, E. (1991). National identity in Northern Ireland. In P. Stringer \& G.

Robinson (Eds.), Social attitudes in Northern Ireland (pp. 23-30). Belfast: Blackstaff Press.

Nasie, M., Diamond, A.H., \& Bar-Tal, D. (2016). Young children in intractable conflicts: The Israeli Case. Personality and Social Psychology Review, 20(4), 365-392.

Nesdale, D. (2004). Social identity processes and children's ethnic prejudice. In M. Bennett, F. Sani (Eds.), The development of the social self (pp. 219-246). London: Psychology.

Nesdale, D. (2007). The development of ethnic prejudice in early childhood. In O. Saracho, B. Spodek (Eds.), Contemporary perspectives on socialization and social development in early childhood education (pp. 213-240). Charlotte, NC: Information Age Publishing.

Nesdale, D., Durkin, K., Maass, A., \& Griffiths, J. (2005). Threat, group identification, and children's ethnic prejudice. Social Development, 14(2), 189-205.

Nesdale, D., Durkin, K., Maass, A., Kiesner, J., Griffiths, J., Daly, J., \& McKenzie, D. (2010). Peer group rejection and children's outgroup prejudice. Journal of Applied Developmental Psychology, 31(2), 134-144.

Nesdale, D., \& Flesser, D. (2001). Social identity and the development of children's group attitudes. Child Development, 72(2), 506-517.

Nesdale, D., Griffiths, J., Durkin, K., \& Maass, A. (2005). Empathy, group norms and children's ethnic attitudes. Applied Developmental Psychology, 26(6), 623-637.

Nesdale, D., Killen, M., \& Duffy, A. (2013). Children's social cognition about proactive aggression. Journal of experimental child psychology, 116(3), 674-692.

Nesdale, D., Maass, A., Durkin, K., \& Griffiths, J. (2005). Group norms, threat, and children's racial prejudice. Child Development, 76(3), 652-663. 
Nesdale, D., Milliner, E., Duffy, A., \& Griffiths, J.A. (2009). Group membership, Group Norms, Empathy, and Young Children's Intentions to Aggress. Aggressive Behaviour, 35(3), 244-258.

Northern Ireland Department of Education. (2017). Integrated schools. https://www.education-ni.gov.uk/articles/integrated-schools

O’Connor, U., Hartop, B., \& McCully, A. (2002). A review of the Schools Community Relations Programme. Bangor: Department of Education.

Olson, K.R., Dweck, C.S., Spelke, E.S., \& Banaji, M.R. (2011). Children's responses to group-based inequalities: Perpetuation and rectification. Social Cognition, 29(3), 270287.

Paulus, M., \& Moore, C. (2014). The development of recipient-dependent sharing behaviour and sharing expectations in preschool children. Developmental Psychology, 50(3), 914-921.

Pinto, I.R., Marques, J.M., Levine, J.M., \& Abrams, D. (2010). Membership status and subjective group dynamics: Who triggers the black sheep effect? Journal of Personality and Social Psychology, 99(1), 107-119.

Police Service of Northern Ireland. (2017). Police Recorded Security Situation Statistics. Retrieved 25 September 2017 from http://www.psni.police.uk/globalassets/inside-thepsni/our-statistics/security-situation-statistics/2017/august/security-situation-statisticsto-august-2017.pdf

Punamäki, R. (1996). Can ideological commitment protect children's psychosocial well-being in situations of political violence? Child Development, 67(1), 55-69.

Reidy, C.M., Taylor, L.K., Merrilees, C.E., Ajdukovíc, D., Čorkalo Biruški, D., \& Cummings, E.M. (2015). The political socialization of youth in a post-conflict community. International Journal of Intercultural Relations, 45, 11- 23. 
Renno, M.P., \& Shutts, K. (2015). Children's social category-based giving and its correlates: Expectations and preferences. Developmental Psychology, 51(4), 533-543.

Rhodes, M., Leslie, S.J., Saunders, K., Dunham, Y., \& Cimpian, A. (2017). How does social essentialism affect the development of inter-group relations? Developmental Science, 21(1), 1-15.

Rutland, A., Killen, M., \& Abrams, D. (2010). A new social-cognitive developmental perspective on prejudice: The interplay between morality and group identity. Perspectives on Psychological Science, 5(3), 279-291.

Rutland, A., \& Killen, M. (2017). Fair resource allocation among children and adolescents: The role of group and developmental processes. Child Development Perspectives, 11(1), 56-62.

Shaw, A., \& Olson, K.R. (2012). Children discard a resource to avoid inequality. Journal of Experimental Psychology: General, 141(2), 382-395.

Sherif, M., Harvey, O.J., White, B.J., Hood, W.E., \& Sherif, C.W. (1961). Intergroup conflict and cooperation: The Robber's Cave Experiment. Norman: University of Oklahoma Book Exchange.

Shirlow, P. (1999). Fear, Mobility and Living in the Ardoyne and Upper Ardoyne Communities. Coleraine: School of Environmental Studies, Ulster University.

Shirlow, P. (2001). Fear and Ethnic Division. Peace Review, 13(1), 67-74.

Shirlow, P. (2003). Who fears to speak: Fear, mobility, and ethno-sectarianism in the two Ardoynes. The Global Review of Ethnopolitics, 3(1), 76-91.

Shirlow, P., \& Murtagh, B. (2006). Belfast: Segregation, violence and the city. London: Pluto Press. 
Shuttleworth, I.G., \& Lloyd, D.L. (2009). Are Northern Ireland's communities dividing? Evidence from geographically consistent Census of Population data, 1971-2001. Environment and Planning A, 41(1), 213-229.

Sloane, S., Baillargeon, R., \& Premack, D. (2012). Do infants have a sense of fairness? Psychological Science, 23(2), 196-204.

Spielman, D.A. (2000). Young children, minimal groups, and dichotomous categorization. Personality and Social Psychology Bulletin, 26(11), 1433-1441.

Stepanikova, I., Triplett, J., \& Simpson, B. (2011). Implicit racial bias and prosocial behaviour. Social Science Research, 40(4), 1186-1195.

Tam, T., Hewstone, M., Kenworthy, J.B., Cairns, E., Marinetti, C., Geddes, L., \& Parkinson, B. (2008). Postconflict reconciliation: Intergroup forgiveness and implicit biases in Northern Ireland. Journal of Social Issues, 64(2), 303-320.

Taylor, L.K., \& Hanna, J.R. (in press). Altruism born of suffering among emerging adults in Northern Ireland. Journal of Aggression, Conflict and Peace Research.

Taylor, L.K., \& McKeown, S. (2017). Youths' peacebuilding potential: Intergroup contact and civic participation amongst a post-accord generation in Northern Ireland. In K. Niven, S. Lewis, \& C. Kagan (Eds.), Making a difference with psychology (pp. 5662). London: Richard Benjamin Trust.

Taylor, L.K., Merrilees, C.E., Goeke-Morey, M.C., Shirlow, P., Cairns, E., \& Cummings, E.M. (2014). Political violence and adolescent outgroup attitudes and prosocial behaviors: Implications for positive intergroup relations. Social Development, 23(4), 840-859.

Taylor, L.K., Merrilees, C.E., Goeke-Morey, M.C., Shirlow, P., \& Cummings, E.M. (2017). Trajectories of adolescent aggression and family cohesion: The potential to perpetuate 
or ameliorate conflict. Journal of Clinical Child andAdolescent Psychology, 45(2), 114-128.

Tropp, L.R., O’Brien, T.C., \& Migacheva, K. (2014). How peer norms of inclusion and exclusion predict interest in cross-ethnic friendships. Journal of Social Issues, 70(1), 151-166.

Verkuyten, M. (2007). Ethnic in-group favouritism among minority and majority groups: Testing the self-esteem hypothesis among pre-adolescents. Journal of Applied Social Psychology, 37(3), 486-500.

Zinser, O., Rich, M.C., \& Bailey, R.C. (1981). Sharing behaviour and racial preference in children. Motivation and Emotion, 5(2), 179-187. 
Table 1. Means, standard deviations, and bivariate correlations of all study variables $(N=88)$

\begin{tabular}{|c|c|c|c|c|c|c|c|c|}
\hline Variables & $M$ & $S D$ & 1 & 2 & 3 & 4 & 5 & 6 \\
\hline 3 Age & 7.52 & 1.40 & -.03 & -.12 & - & & & \\
\hline 5 Outgroup attitudes & 8.35 & 2.70 & .02 & -.02 & -.14 & .15 & - & \\
\hline 6 Ingroup giving & 3.41 & 1.47 & .15 & $.37^{* * *}$ & .01 & .13 & $-.22^{*}$ & - \\
\hline 7 Outgroup giving & 3.01 & 1.48 & -.07 & .04 & -.12 & -.01 & $.29^{* *}$ & $-.72^{* * *}$ \\
\hline
\end{tabular}

Note: $* p<.05, * * p<.01,{ }^{* * *} p<.001$. 
Figure 1: Number of stickers given to an ingroup and outgroup child by neighborhood type

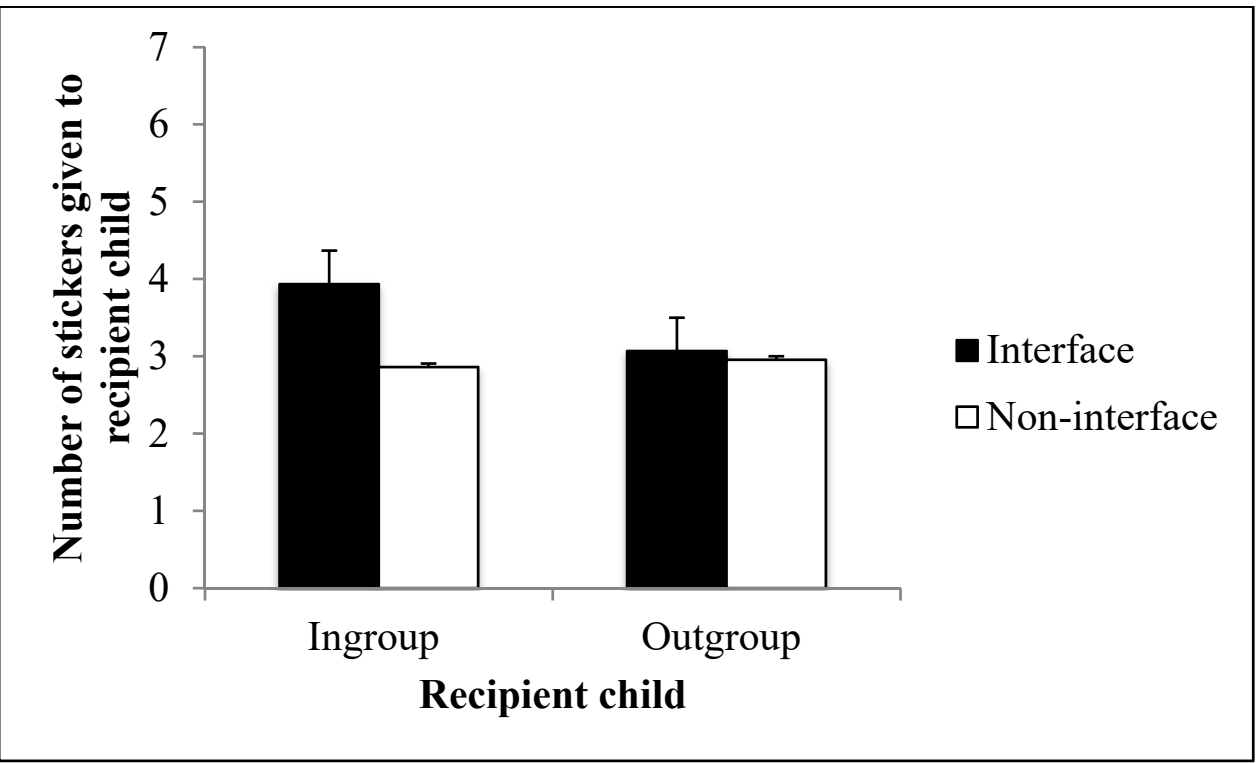


Figure 2: The interaction between strength of ingroup identity and neighborhood type predicting ingroup giving. Higher and lower strength of ingroup identity scores are plotted at one standard deviation above and below the mean.

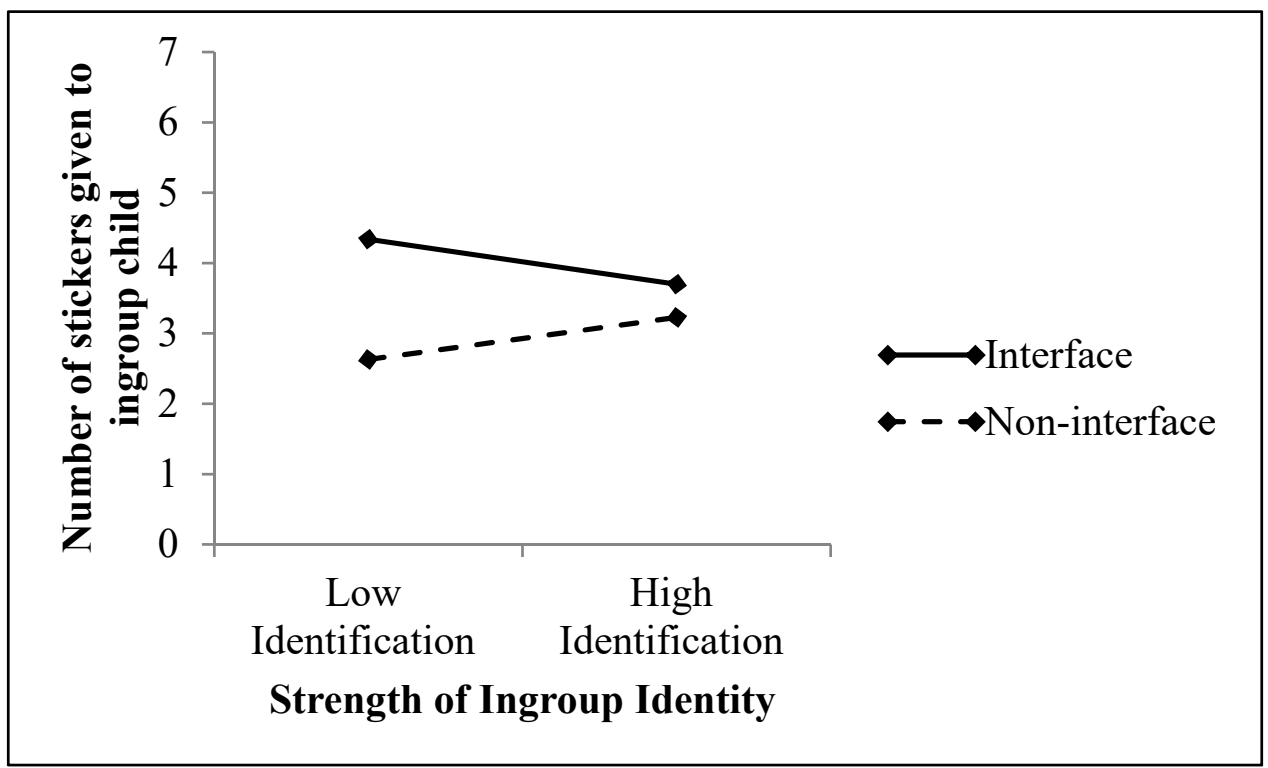


Figure 3: The interaction between outgroup attitudes and neighborhood type predicting outgroup giving. Higher and lower outgroup attitude scores are plotted at one standard deviation above and below the mean.

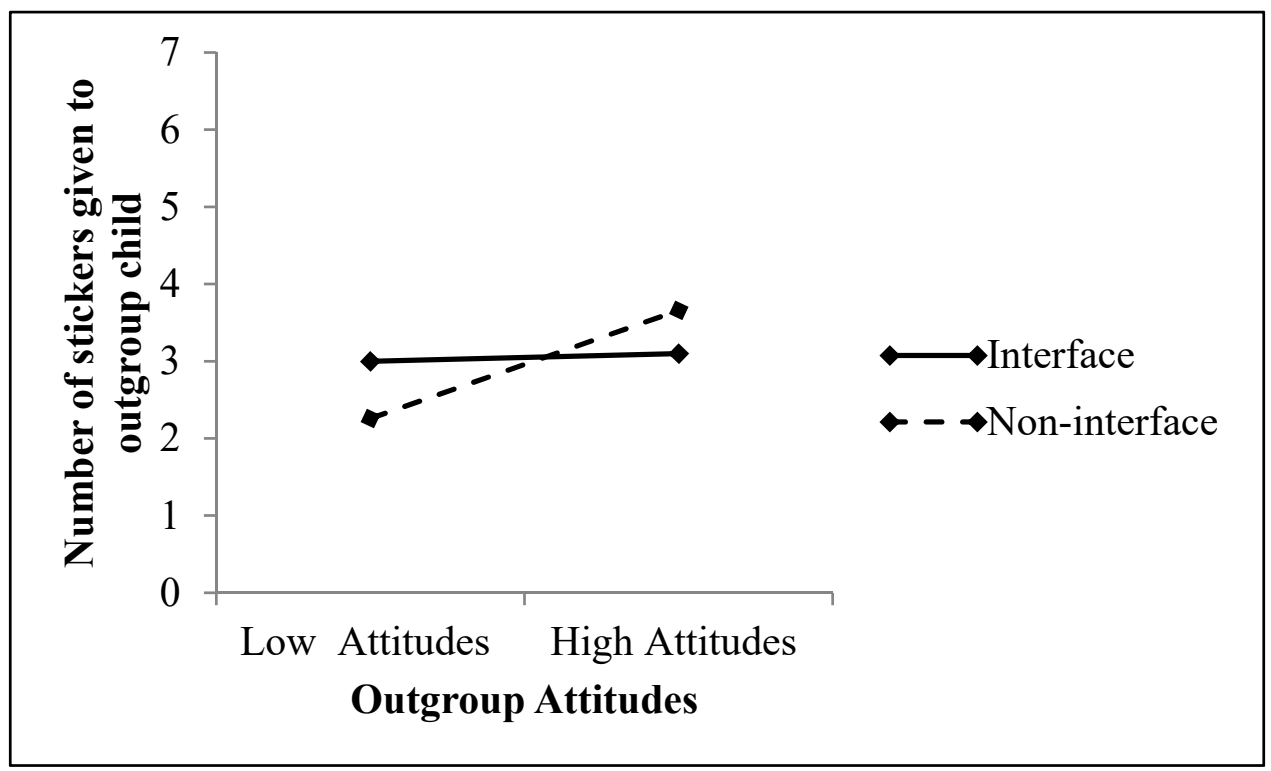

